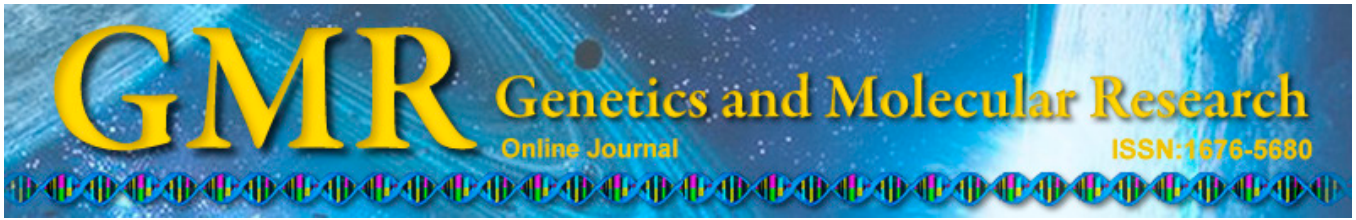

\title{
Efficacy of combined hepatitis B immunoglobulin and hepatitis $B$ vaccine in blocking father-infant transmission of hepatitis $B$ viral infection
}

\author{
L.-H. Cao ${ }^{1}$, Z.-M. Liu ${ }^{1}$, P.-L. Zhao ${ }^{1}$, S.-C. Sun ${ }^{2}$, D.-B. Xu' ${ }^{1}$, M.-H. Shao ${ }^{1}$ \\ and J.-D. Zhang ${ }^{1}$
}

${ }^{1}$ Hepatic Disease Center, The Third Hospital of Qinhuangdao City, Hebei, Qinhuangdao, China

${ }^{2}$ Maternal and Child Hospital of Qinhuangdao City, Hebei, Qinhuangdao, China

Corresponding author: L.-H. Cao

E-mail: caolihua_clh@163.com

Genet. Mol. Res. 14 (2): 4651-4657 (2015)

Received July 25, 2014

Accepted October 30, 2014

Published May 4, 2015

DOI http://dx.doi.org/10.4238/2015.May.4.24

\begin{abstract}
The aim of this study was to examine the efficacy of combined immunization of hepatitis B immunoglobulin (HBIG) and hepatitis B vaccine (HBVac) in blocking father-infant transmission of hepatitis B virus (HBV). Newborns positive at birth for blood HBV surface antigen (HBsAg) and/or HBV DNA were selected and immunized with HBIG combination HBVac. At 7 months, HBV markers and HBV DNA of each neonate were measured using electrochemiluminescence with the Cobas-e-411 Automatic Electrochemiluminescence Immunoassay Analyzer and fluorescence quantitative polymerase chain reaction. Among all 7-month-old subjects, the negative conversion rates of HBV DNA and HBsAg were 48/61 (78.7\%) and 19/41 (46.3\%), respectively. Therefore, this study demonstrated that prompt combination
\end{abstract}


injection of HBIG and HBVac can protect some of the HBV DNA- and/ or HBsAg-positive newborns from HBV.

Key words: Combined immunization; Blocking effect; HBV; Father-infant transmission

\section{INTRODUCTION}

In 1985, Hadchouel et al. (1985) found hepatitis B virus (HBV) DNA integrated in the sperm DNA of patients with acute hepatitis B infection using molecular hybridization, proving for the first time the existence of father-infant transmission. At almost the same time, Tajiri et al. (2007) discovered molecular evidence for this route of infection, turning fatherinfant transmission from a hypothesis to accepted reality HBV can be transmitted from father to child in two ways, horizontal and vertical. It is generally acknowledged that the former can be blocked by joint injection of hepatitis B immunoglobulin (HBIG) and hepatitis B vaccine (HBVac) after the child's birth. However, when it comes to vertical transmission, conventional ideas suggest that it should be impeded before pregnancy, due to the potential for its spreading throughout the germ cells (Ni and Zeng, 2006; Chen and She, 2013). However, a few recent studies have reported the negative conversion following immunization of HBV DNA $(+)$ and/ or HBsAG $(+)$ children who were infected in utero or at birth (Chen et al., 2007). This study was designed to survey the efficacy of combined immunization of HBIG and HBVac in blocking father-infant vertical transmission of HBV.

\section{MATERIAL AND METHODS}

\section{Subjects}

Observation group: Neonates with blood HBV DNA $(+)$ and/or HBsAg $(+)$ at birth were selected for this study. Criteria for inclusion were: 1) informed consent signed by parents; 2) all subjects had HBV DNA (+), HBsAg (+) fathers with an infection history of 2 to 23 years, and mothers who were all negative in the HBV viral marker (HBVM) index or who were solely positive for anti-HBs or anti-HBc; 3) parents were without infection by hepatitis $\mathrm{A}, \mathrm{C}, \mathrm{D}$, or E virus, or human immunodeficiency virus, and with no record of alcoholic hepatitis, renal, or autoimmune liver disease; 4) parents were untreated before or during pregnancy; 5) venous blood samples of the neonates had been collected as cord blood that remained in the placenta and umbilical cord after cord deligation and transection, wherein there might be the possibility of maternal blood contamination from normal labor or cesarean section.

Control group: Newborns with healthy parents (no detectable HBV infection) and who were born during the same period were selected.

\section{Specimen collection and outcome measures}

Venous blood samples from the neonates were collected immediately after birth and detection of HBVM and HBV DNA was performed.

Seven months after the joint injection of HBIG and HBVac at birth, HBVM and HBV DNA levels in the subjects' venous blood were measured again. 


\section{Sample detection}

For each newborn, the levels of HBVM and HBV DNA were measured using the same blood sample. HBVM was measured by electrochemiluminescence using the Cobas-e-411 Automatic Electrochemiluminescence Immunoassay Analyzer. The reagent was provided by Roche Diagnostics Co., Ltd. (Germany). HBV DNA was measured by fluorescence quantitative polymerase chain reaction (PCR) using a Fluorescence Quantitative PCR Instrument (SLAN) from San Xiang Biotechnology Co., Ltd. (Hunan, China); relevant reagents were also supplied by San Xiang, according to the PCR manual (Jeffrey et al., 2006).

\section{Research methods}

For the observation group, the research was divided into two phases. In phase one, of all the neonates in accordance with the above inclusive criteria, a total number of 1957 were selected whose parents had undergone initial treatment and follow-up at our hospital's liver clinic, or had received their prenatal care at Qinhuangdao Maternal and Child Hospital, since March 2006. Among these parents, all fathers were HBV DNA-positive. All fathers had one of three results for $\mathrm{HBVM}$ blood tests: $\mathrm{HBsAg}(+), \mathrm{HBeAg}(+)$, and anti- $\mathrm{HBc}(+)$; $\mathrm{HBsAg}(+)$, anti-HBe $(+)$, and anti-HBc $(+)$; or $\mathrm{HBsAg}(+)$ and anti-HBc $(+)$. Meanwhile, of all mothers, $29.7 \%(581 / 1957)$ were HBsAg (-), anti-HBs $(+)$; 30.3\% (593/1957) were anti-HBs $(+)$, anti$\mathrm{HBe}(+)$, anti-HBc $(+)$, or anti-HBs $(+)$, anti-HBc $(+) ; 10.1 \%$ (197/1957) were solely anti-HBc $(+)$; and another $29.9 \%(586 / 1957)$ of all the mothers had all negative HBVM results. In addition, none of the selected mothers were $\operatorname{HBsAg}(+)$.

During phase two, blood samples were taken from all selected 1957 neonates (there had been no cases of intervening death). Among the 581 neonates with anti-HBs $(+)$ mothers, none were HBV DNA $(+)$ and only one $(0.17 \%)$ was HBsAg $(+)$. Among the 593 neonates with anti-HBs $(+)$, anti-HBe $(+)$, and anti-HBc $(+)$, or anti-HBs $(+)$, and anti-HBc $(+)$ mothers, 28 $(4.72 \%)$ were HBV DNA $(+)$, and $19(3.20 \%)$ were HBsAg $(+)$. Among the 783 neonates with anti-HBsAg (-) mothers [including the 586 neonates with mothers negative for all markers and the 197 with mothers solely anti-HBc (+)] 33 (4.21\%) were HBV DNA (+) and $21(2.68 \%)$ were HBsAg $(+)$.

In the observation group, $61 \mathrm{HBV}$ DNA $(+)$ and $41 \mathrm{HBsAg}(+)$ neonates all received combined immunization of HBIG (200 IU within $6 \mathrm{~h}$ after birth and another $200 \mathrm{IU}$ when 3-4 weeks old) and HBVac (three injections of $20 \mu \mathrm{g}$, at 0,1 , and 6 months).

Simultaneously, 1949 uninfected neonates (whose parents also were without HBV infection) born at the same period were selected as the control group.

\section{Statistical analysis}

The Student $t$ - test was used for measurement data, and the $\chi^{2}$ test was used for count data. The SPSS16.0 statistical software (SPSS, Chicago, IL, USA) was used for data analysis, and $\mathrm{P}<0.05$ was considered as statistically significant.

\section{RESULTS}

Basic information of subject parents is displayed in Tables 1 and 2. 
Table 1. Basic information of fathers in both groups.

\begin{tabular}{lcccc}
\hline & $\mathrm{N}$ & Age (years) & Height $(\mathrm{cm})$ & Weight $(\mathrm{kg})$ \\
\hline Observation group & 1957 & $30.1 \pm 2.6$ & $177.1 \pm 5.6$ & $66.5 \pm 5.2$ \\
Control group & 1949 & $27.6 \pm 2.9$ & $175 \pm 6.4$ & $65.4 \pm 5.3$ \\
$\chi^{2}(t)$ & & 1.112 & 0.428 & 0.257 \\
P value & & 0.329 & 0.691 & 0.810 \\
\hline
\end{tabular}

Table 2. Basic information of mothers in both groups.

\begin{tabular}{lccccc}
\hline & $\mathrm{N}$ & Age (years) & Height $(\mathrm{cm})$ & Weight $(\mathrm{kg})$ & Gravidity \\
\hline Observation group & 1957 & $26 \pm 2.4$ & $162 \pm 5.2$ & $56.2 \pm 5.2$ & $2 \pm 1.0$ \\
Control group & 1949 & $25 \pm 2.0$ & $159.1 \pm 5.5$ & $54 \pm 5.9$ & $2 \pm 1.0$ \\
$\chi^{2}(t)$ & & 0.554 & 0.664 & 0.485 & 0 \\
P value & & 0.609 & 0.543 & 0.653 & 1 \\
\hline
\end{tabular}

Complications during pregnancy in both groups are shown in Table 3.

Table 3. Complications during pregnancy in both groups.

\begin{tabular}{lcccc}
\hline & $\mathrm{N}$ & Hypertension & Preeclampsia & Diabetes \\
\hline Observation group & 1957 & 21 & 0 & 0 \\
Control group & 1949 & 16 & 0 & 0 \\
$\chi^{2}(t)$ & & 0.662 & & \\
P value & & 0.416 & & \\
\hline
\end{tabular}

The general state of health of the selected newborns is shown in Table 4.

\begin{tabular}{|c|c|c|c|c|}
\hline Item & Observation group (1957 cases) & Control group (1949 cases) & $\chi^{2}(t)$ & P value \\
\hline Gestational age & $39.25 \pm 1.23$ & $39.11 \pm 1.33$ & 0.134 & 0.900 \\
\hline Birth weight $(\mathrm{kg})$ & $3.32 \pm 0.31$ & $3.35 \pm 0.33$ & 0.115 & 0.914 \\
\hline Birth length $(\mathrm{cm})$ & $49.72 \pm 1.58$ & $49.60 \pm 1.52$ & 0.095 & 0.929 \\
\hline Gender $(\mathrm{M} / \mathrm{F})$ & $1001 / 956$ & 996/953 & 0.001 & 0.977 \\
\hline \multicolumn{5}{|l|}{ Apgar score } \\
\hline At $1 \mathrm{~min}$ & $9.95 \pm 0.51$ & $9.79 \pm 0.49$ & 0.392 & 0.715 \\
\hline \multicolumn{5}{|l|}{ Apgar score } \\
\hline At $8 \mathrm{~min}$ & $9.96 \pm 0.59$ & $9.83 \pm 0.58$ & 0.272 & 0.799 \\
\hline Jaundice & 25 & 19 & 0.803 & 0.370 \\
\hline Other diseases & 0 & 0 & & \\
\hline Mode of delivery $(\mathrm{CS} / \mathrm{NL})$ & $1002 / 955$ & $998 / 951$ & 0.000 & 0.998 \\
\hline
\end{tabular}

$\mathrm{M}=$ male $; \mathrm{F}=$ female $\mathrm{CS}=$ Caesarian section; $\mathrm{NL}=$ normal labor.

\section{Blood test results}

Among the 783 neonates who were anti-HBsAg (-) [including 586 with mothers negative for all markers and 197 with solely anti-HBc $(+)$ mothers], 33 (4.21\%) were HBV DNA $(+)$ and $21(2.68 \%)$ were HBsAg $(+)$.

Among the 581 neonates with anti-HBs $(+)$ mothers, plus the 593 neonates with antiHBs $(+)$, anti-HBe $(+)$, anti-HBc $(+)$, or anti-HBs $(+)$, and anti-HBc $(+)$ mothers, 28/1174 (4.72\%) were HBV DNA (+) and 20/1174 (3.20\%) were HBsAg $(+)$. 
Of all 1957 selected newborns, the total positive rate of HBV DNA was 3.11\% (61/1957), while that of HBsAg was 2.09\% (41/1957). Detailed results are shown in Table 5.

Table 5. Positive rate for HBVM and HBV DNA in all neonates.
\begin{tabular}{lccccc}
\hline & N & HBV DNA $(+)$ & HBsAg $(+)$ & $\chi^{2}$ & P value \\
\hline Observation group & 1957 & 61 & 41 & 4.027 & 0.045 \\
Control group & 1949 & 0 & 0 & & \\
\hline
\end{tabular}

$\mathrm{HBVM}=\mathrm{HBV}$ markers; HBsAg $=\mathrm{HBV}$ surface antigen.

Overall, after joint injection, the negative conversion rate of HBV DBA $(+)$ neonates was 48/61 (78.7\%), and that of HBsAg (+) neonates was 19/41 (46.3\%).

\section{DISCUSSION}

\section{HBV vertical transmission from father to infant and its transmission rate}

Ever since Blumberg (1977) conjectured from family surveys that there might be HBV DNA integration in patient germ cells, causing vertical transmission from parents to infants, a growing number of researchers have detected HBV DNA from patient semen and sperm, confirming Blumberg's conjecture. As transgenic technology has developed, further studies regarding the mechanism of spreading of HBV through germ cells have been carried out. In these studies (Araki et al., 1989; Huang et al., 2002), patient semen was used to fertilize zonafree eggs from the golden hamster, and a hybridization signal of an HBV probe was found in sperm chromosomes, suggesting that sperm with integrated HBV DNA could complete the entire fertilization process rather than be selectively eliminated. It has since been confirmed that sperm can not only carry but might even draw in HBV DNA, and yet remain unaffected in fertilizing ability in most cases (Ali et al., 2005). In 2006, sperm-mediated HBV DNA was detected to be replicating and expressing in early embryonic cells, providing direct evidence for vertical transmission from father to infant (Ali et al., 2006). There are two pathways of HBV transmission from father to child: horizontal and vertical. When HBV is passed on from father to infant through daily contact, it is defined as horizontal transmission, which can be efficiently blocked by joint injection of HBIG and HBVac. When HBV is passed on to the child through the father's sperm, it is defined as vertical transmission. Vertical transmission from father to child is more likely to occur when the father is HBsAg-, HBeAg-, and HBcAb-positive, and it has become the second most important mechanism of vertical transmission (just below mother-to-child vertical transmission) (Komatsu et al., 2009). The research of Huang et al. (2003) suggested that infection by HBV could cause chromosomal mutation in patient sperm, and that integration of HBV DNA into sperm chromosomes is a random and multi-locus event, increasing the instability of sperm chromosomes and causing widespread influence lasting for generations. Other studies (Ali et al., 2005; Takegoshi and Zhang, 2006; Komatsu et al., 2009) indicated that infants with HBsAg $(+)$ fathers were the highest risk group for vertical transmission. However, the reported transfection rates were variable (Wang et al., 2003b; Cai and Zhu, 2013), probably because of different diagnostic criteria applied and different populations selected across studies. Our study showed that when fathers are HBsAg $(+)$ as well as HBV DNA (+), the total positive rate of HBV DNA in their infants is $3.11 \%(61 / 1957)$, while that of HBsAg is $2.09 \%$ 941/1957). 


\section{General health status of newborns}

In our study, there were no significant differences in gestational age, birth weight, birth length, Apgar score at 1 or 8 min, jaundice, mode of delivery, or other diseases between the observation and control groups, and there were no cases of malformation or death in either group. This result suggests that a risk of vertical transmission of HBV [with the father being HBsAg $(+)$ ] had no significant effect on the fetus in the above aspects (see the results in Table 4). Our conclusion contradicts that of many other researchers in which chromosome aberration in patients with HBV infection was suggested to be a significant risk factor for infertility, spontaneous abortion, fetal death, fetus malformation, and perinatal infant mortality (Livezey et al., 2002; Huang et al., 2003; Vicari et al., 2006; Ye et al., 2014).

\section{HBV index of neonates at birth}

In our study, the total positive rate of neonate HBV DNA was higher than that of HBsAg, and was compatible with the results of Zhong et al. (1995). However, blood test results for HBVM do not always match those for HBV DNA. For example, in a study by Wang et al. (2003a), 16 infants infected by their fathers were all HBV DNA $(+)$, while no positive result was detected for HBVM. He et al. (2005) also showed that the total detection rate of infant HBV DNA was significantly higher than that of HBsAg. Most researchers believe that during the embryonic stage, serological markers of HBV are not expressed as a consequence of the immature immune system and because of immunological impact from the mother, such that it would only be possible to detect HBV DNA in the fetal blood serum, leukocytes, and liver. With the improvement of the neonate immune function after birth, the virus would be cleared in most infected infants, and only a small portion of these infants would become stable, sustainable carriers, wherein serological markers would be detectable due to virus replication in large amounts.

\section{Blood test results of infected 7-month-old subjects who had accepted joint injection of HBIG and HBVac}

HBIG can neutralize and eliminate HBV in the blood, extracellular fluid, and on mucosal surfaces; however, it can only stay in the body fluid and cannot enter liver cells. Therefore, HBIG must be injected as soon as possible after birth (positive effects decline after 48 $\mathrm{h}$, and disappear after 7 days) in order to reach optimum effects before the virus enters liver cells. Circulating anti-HBs rise to a protective level 2-3 h after HBIG injection, and peak at 2-5 days; their average half-life is $24.0 \pm 3.8$ days. In our study, the time points and dosage of HBIG injection were $200 \mathrm{IU}$ within $6 \mathrm{~h}$ repeated at 3-4 weeks; injections of HBVac $(20 \mu \mathrm{g})$ were at 0,1 , and 6 months (Gao, 1993; Chen et al., 2007).

In conclusion, our results suggest that although being HBVM and HBV DNA (+), some infants might be protected from future HBV infection by combined immunization of HBIG with HBVac. This finding, and similar results from several other studies (Chen et al., 2007), might arise from the blocking effect of anti-HBs stimulated by vaccination. Anti-HBs can protect new cells, especially new hepatic cells of an infant from HBV infection spread from the small amount of cells infected during the embryonic stage; therefore combined immunization soon after birth is of great importance. In this study, for reasons of medical ethics, 
we did not utilize a negative (non-vaccinated) control, so an increase in sample size and follow-up time is still needed to validate our results. Thus far, however, our study has indicated combined immunization to be of great impact in protecting the fetus from paternal HBV transmission.

\section{REFERENCES}

Araki K, Miyazaki J, Hino O, Tomita N, et a1. (1989). Expression and replication of hepatitis B virus genome transgenic mice. Proc. Natl. Acad. Sci. U. S. A. 86: 207-211.

Ali BA, Huang TH and Xie QD (2005). Detection and expression of hepatitis B virus X gene in one and two-cell embryos from golden hamster oocytes in vitro fertilized with human spermatozoa carrying HBV DNA. Mol. Reprod. Dev. 70: $30-36$.

Ali BA, Huang TH, Salem HH and Xie QD (2006). Expression of hepatitis B virus genes in early embryonic cells originated from hamster ova and human spermatozoa transfected with the complete viral genome. Asian J. Androl. 8: 273-279.

Blumberg BS (1977). Australia antigen and the biology of hepatitis B. Science 197: 17-25.

Cai QX and Zhu YY (2013). Is hepatitis B virus transmitted via the male germ line? A seroepidemiological study in fetuses. Int. J. Infect. Dis. 17: e54-58.

Chen H, Wang XY and Lu X (2007). Neonatal infection with hepatitis B virus antigen positive official overcast Case Report and Analysis. Chin. J. Neonatol. 22: 306-307.

Chen ZQ and She YP (2013). Blocking studies parent-child transmission of hepatitis B virus. Huaxia Yi Xue 26: 930-932.

Gao SZ (1993). Control of viral hepatitis. 1st edn. Beijing Publishing House, Beijing. 32-45.

Hadchouel M, Scotto J, Huret JL, Molinie C, et al. (1985). Presence of HBV-DNA in spermatozoa: a possible vertical transmission of HBV via the germ line. J. Med. Virol. 16: 61-66.

He JQ, Yuan SH, Xian GJ, et al. (2005). Clinical studies of HBV vertical transmission from father to infant. Pract. Obstet. Gynecol. 21: 301-302.

Huang JM, Huang TH, Qiu HY, Fang XW, et al. (2002). Studies on the integration of hepatitis B virus DNA sequence in human sperm chromosomes. Asian J. Androl. 4: 209-212.

Huang JM, Huang TH, Qiu HY, Fang XW, et al. (2003). Effects of hepatitis B virus infection on human sperm chromosomes. World J. Gastroenterol. 9: 736-740.

Jeffrey JG, Mohammed OQ, Jayawant NM, Shawn Mitchell P, et al. (2006). Quantification of Hepatitis B Virus (HBV) DNA with a TaqMan HBV Analyte-Specific Reagent following Sample Processing with the MagNA Pure LC Instrument. J. Clin. Microbiol. 44: 1490-1494.

Komatsu H, lnui AI, Soqo T, Hiejima E, et al. (2009). Source of transmission in children with chronic hepatitis B infection after the implementation of a strategy for prevention in those at high risk. Hepatol. Res. 39: 569-576.

Livezey KW, Negorev D and Simon D (2002). Increased chromosomal alterations and micronuclei formation in human hepatoma HepG2 cells transfected with the hepatitis B virus HBX gene. Mutat. Res. 505: 63-74.

Ni XP and Zeng XY (2006). Whether the mother before pregnancy HBsAb clinical contrast parent-child transmission of HBV. Pract. Clin. Integr. Med. 6: 56-57.

Tajiri H, Tanaka Y, Kagimoto S, Murakami J, et al. (2007). Molecular evidence of father-to-child transmission of hepatitis B virus. J. Med. Virol. 79: 922-926.

Takegoshi K and Zhang W (2006). Hepatitis B virus infection in families in which the mothers are negative but the fathers are positive for HBsAg. Hepatol. Res. 36: 75-77.

Vicari E, Arcoria D, Di Mauro C, Noto R, et al. (2006). Sperm output in patients with primary infertility and hepatitis B or $\mathrm{C}$ virus; negative influence of HBV infection during concomitant varicocele. Minerva Med. 97: 65-77.

Wang SS, Li WL, Peng GF, Li MM, et al. (2003a). The analysis of S gene phylogenetic tree of HBV in transmission from father to infant. Zhonghua Yi Xue Za Zhi 83: 451-454.

Wang SS, Peng GF, Li MM, Xiao H, et al. (2003b). Identification of hepatitis B virus vertical transmission from father to fetus by direct sequencing. Southeast Asian J. Trop. Med. Public Health 34: 106-113.

Ye F, Liu Y, Jin Y, Shi J, et al. (2014). The effect of hepatitis B virus infected embryos on pregnancy outcome. Eur. J. Obstet. Gynecol. Reprod. Biol. 172: 10-14.

Zhong L, Qi HB, Hu LN, Cai HZ, et al. (1995). The polymerase chain reaction technique to detect the spread of hepatitis $\mathrm{B}$ virus in the womb. Zhonghua Fu Chan Ke Za Zhi 30: 553-554. 